\title{
ACCESSIBLE TOURISM FOR ALL - CURRENT STATE IN THE CZECH BUSINESS AND NON-BUSINESS ENVIRONMENT
}

\author{
Ivica Linderová, Petr Janeček
}

\section{Introduction}

Tourism is a sector of remarkable economic importance. It is currently one of the most dynamically developing sectors of the economy. It provides huge opportunities for socio-economic development (Maráková, Dyr, \& Wolak-Tuzimek, 2016). According to the World Tourism Organisation (UNWTO), the European tourism economy contributes about $5 \%$ (depending on its definition up to $11 \%$ ) to the GDP of the European Union and provides between 8 and 24 million jobs (depending on the definition of the sector). Tourism development has numerous economic and socio-cultural impacts on the regional economy, entrepreneurship and local businesses.

Nowadays, new ways to develop tourism are being discovered. One of them is accessibility and social policy aspects.

The aim of the paper is to map the possibilities for people with physical disabilities to participate in tourism in the Czech Republic. The paper is organized into two parts. The first part focuses on a review of the literature in the field of accessible tourism and disability. The second part deals with conditions of accessible tourism services in the Czech business and non-business environment. We focused on accommodation facilities, catering facilities, tourist routes and cycle routes and UNESCO heritage. The situation in all 14 administrative regions was evaluated. The research was conducted from 2013 to 2016.

Accessible tourism facilities are an impulse for accessible tourism development. Accessible tourism is a part of social tourism. In the context of the ageing of the world population, a focus on social tourism is even more important. The term "tourism for all" is used by the European Union for social tourism. This term often refers to very different aspects. Sometimes, in particular in a social policy context, it is used to underline the need to facilitate holidays for lower income groups, sometimes to take into account the needs of disabled visitors (Leidner, 2006).

Minnaert (2014) says that social tourism is tourism that specifically encourages the participation in tourism activities of people who are economically weak or otherwise disadvantaged. Cazes (2000) sees social tourism as a complex phenomenon, which allows tourism participation for disadvantaged persons. It respects human rights as the right to holiday and the right to tourism, it is based on a non-profit concept and it accepts the social and financial situation of participants. According to Cazes (2000), the aim of social tourism is the active use of leisure time, the physical and cultural development of participants. McCabe (2009; 2010), Darcy (2010), Shi et al. (2012), Eichorn et al. (2013), Garcés Ferre et al. (2015), Michopoulou (2015) also deal with social tourism.

In practice, social tourism addresses four main target groups - senior citizens, young people, low-income families and people with disabilities. The majority of these target groups have special requirements during their travels and holidays. Disabled visitors and seniors are groups with the biggest needs. They have limited mobility and need a special environment.

In the context of accessibility for people with physical disabilities it is preferable to speak about accessible tourism for all. It is a form of tourism that involves a collaborative process among stakeholders that enables people with access requirements, including mobility, vision, hearing and cognitive dimensions of access, to function independently and with equity and dignity through the delivery of universally designed tourism products, services and environments (Linderová, 2015).

Accessible tourism for all is not about creating separate services for disabled people, it aims at 
full integration, or rather the inclusion of people with special needs, in particular, disabled and aged people, in the tourism sector. Viewed from the perspective of accessible tourism for all, the tourism policy in the European Union can be said to unite accessibility targets that are part of the otherwise commerce-related aspects of the tourism policy and a disability policy that, based on the UN's Standard Rules, support goals and specific measures at various levels that are designed to enhance accessibility in connection with tourism policy (Leidner, 2008).

The long-term goal of the tourism accessible for all movement is the creation of a tourist environment in which all tourists, irrespective of their individual needs (age, size, (dis)ability) can participate actively (Leidner, 2008).

The definition of Tourism for All adopted by the Nordic Council on Disability Policy underlines this approach: Everyone regardless of whether they have any disabilities - should be able to travel to the country, within the country and to whatever place, attraction or event they should wish to visit (Leidner, 2006).

\section{Accessibility as a Factor of Tourism Development}

We could imagine a lot of possibilities under the term accessibility. Accessibility can be understood as barrier-free access to hotels, restaurants, museums, castles, etc. It also means financial accessibility for low-income families, seniors and socially disadvantaged people.

According to international law, e.g., the Convention of the UN, the Global Code of Ethics for tourism and national legislation in European countries, the right to tourism is held by everybody. Nationality, sex, age and religion are not important.

The Global Code of Ethics for tourism says that tourism activities should respect the equality of men and women; they should promote human rights and, more particularly, the individual rights of the most vulnerable groups, notably children, the elderly, the handicapped, ethnic minorities and indigenous peoples. The prospect of direct and personal access to the discovery and enjoyment of the planet's resources constitutes a right equally open to all the world's inhabitants.

By looking at tourism, transport and disability, Cavinato and Cuckovich (1992, in Darcy \& Buhalis, 2011) refer to access in terms of dealing with and addressing a wide range of constraints. Darcy (1998, in Darcy \& Buhalis, 2011) divides the term access into three dimensions: physical access, sensory access and communication access. Darcy (1998) views these three dimensions as an inclusive marketing process, which allows tourism players to realise the potential of accessibility for the marketing of tourism products and services to the widest possible client base.

Usability and universal design are also related to the term access and accessibility. The universal design addresses the inclusion of the entire population, incorporates aspects of accessibility and usability at the beginning and represents a less stigmatising concept (Iwarsson \& Ståhl, 2003, in Darcy \& Buhalis, 2011).

\subsection{Disability with an Emphasis on Physical Disadvantages}

According to the World Health Organization (2011), there are approximately 1 billion persons with disabilities in the world. This equates to approximately $15 \%$ of the world population having a physical, mental or sensory disability. In Canada 3.6 million people live with disability, in the United Kingdom 8.5 million people, in the USA 54 million people, and around Europe 60 million people (European Commission, 2008).

Due to the ageing population in industrialized countries, the rate of disability among people with the capacity to travel is also increasing, adding to the demand for an accessible environment, transport and services - thereby adding to the market value of the accessible tourism segment (Rahman, 2005).

Disability can be defined as limitations on possibilities to participate in the life of society at the same level as other people that is due to architectural or social barriers (Shaw \& Coles, 2004).

According to the World Health Organization (WHO), different terms are used. WHO differentiates impairment, disability and handicap.

In the context of health experience, an impairment is any loss or abnormality of a psychological, physiological, or anatomical structure of the function. A disability is any restriction or lack (resulting from an impairment) of ability to perform an activity in the manner or within the range considered normal for a human being. A handicap is a disadvantage for a given individual resulting from an impairment or 
a disability that limits or prevents the fulfilment of a role that is normal (depending on age, sex, and social and cultural factors) for that individual (WHO, 1980).

Persons with disabilities includes all persons who, owing to the environment being encountered, suffer a limitation in their relational ability and have special needs during travel, in accommodation, and other tourism services, particularly individuals with physical, sensory and intellectual disabilities or other medical conditions requiring special care, such as elderly persons and others in need of temporary assistance (UNWTO, 2005).

While access, involving a range of barriers, is shown to be an issue for the disabled, physical access is but one issue, with other constraints often being more significant to this group. There is an important segment of disabled people for whom removing the barriers of physical access is only part of the problem. For this group, holidays are not possible because of financial restrictions. These are clearly associated with disabilities as these restrict access to the world of work (Shaw \& Coles, 2004, in Lovelock \& Lovelock, 2013).

When speaking about accessible tourism for all, it is important to define physical disability. Physical disability represents an impairment or defect in the motoric and musculo-skeletal systems, i.e., bones, joints, tendons, muscles, vascular and nervous systems if it is manifested by an impaired ability to move (mobility).
Mobility impairment can be a result of heredity, disease or injury, and inner and outer factors can be considered among the reasons (Renotiérová, 2006). Vítková (1998) classifies movement disabilities as central and peripheral paralyses (e.g., cerebral palsy), deformations, malformations, and amputations.

The shared feature of disabled people is a reduction in usual activities and in some cases also partial to complete immobility (Novosad, 2005).

Buřvalová and Reitmayerová (2007) understand physical disability as a mobility defect in terms of functional limitations, i.e., something does not work in comparison with the standard, or as physical deformation in terms of aesthetic impairment, i.e., something that is not accepted very positively by others. Filipiová (1998) divides types of physical disabilities into four categories in Tab. 1.

According to the findings of the Czech Statistical Office, in the Czech Republic live 54,831 people with physical disabilities (data from 2013). These people represent $36 \%$ of all health impaired persons in the country. Compared with 2007, when the share of physical impairments in all health disabilities was $29 \%$, it means an increase.

\subsection{Barrier-Free Solutions in Tourism}

A variety of authors have endeavoured to group barriers and constraints in tourism opportunities into categories, e.g., Smith (1987), Darcy and

\section{Tab. 1: Categories of physical disabilities according to used aids}

\begin{tabular}{|c|c|c|}
\hline $\begin{array}{l}\text { 1st category } \\
\text { lighter physical disability }\end{array}$ & & $\begin{array}{l}\text { people using crutches } \\
\text { result of injury, worn-out joint }\end{array}$ \\
\hline $\begin{array}{l}\text { 2nd category } \\
\text { medium physical disability }\end{array}$ & a) & $\begin{array}{l}\text { crutches, orthopedic prosthetics (splints, braces) } \\
\text { difficulties when walking, standing up or walking up stairs }\end{array}$ \\
\hline $\begin{array}{l}\text { 3rd category } \\
\text { severe physical disability } \\
\text { (people in wheelchairs) }\end{array}$ & a) & $\begin{array}{l}\text { people who cannot stand for a longer period of time, who have } \\
\text { undergone amputation of lower limbs, elderly people } \\
\text { people permanently confined to a wheelchair; only in sporadic } \\
\text { need of assistance } \\
\text { people confined to a wheelchair; in some situations, in need } \\
\text { of assistance } \\
\text { people confined to a wheelchair; assistance necessary } 24 \text { hours } \\
\text { a day } \\
\text { people confined to a powered wheelchair }\end{array}$ \\
\hline $\begin{array}{l}4 \text { th category } \\
\text { very severe physical disability }\end{array}$ & a) & $\begin{array}{l}\text { disease manifests itself slowly and goes gradually through all } \\
\text { the above-mentioned categories }\end{array}$ \\
\hline
\end{tabular}


Darruwalla (1999), Israeli (2002), Shaw and Coles (2004), Daniels et al. (2005), Goodall (2006), Arab-Moghaddam et al. (2007). Packer et al. (2007), Yates (2007). According to Darcy \& Buhalis (2011) three categories are employed that can be addressed by the tourism industry: physical access constraints, attitudinal barriers and lack of information.

The tourist product is complex and consists of goods and services gathered and offered to the client (Buiga et al., 2017). Persons with disabilities have special needs. So, it is usable for them to adapt different elements in tourism destination.

Adapted parking areas are fundamental. Special parking spaces with proper identification for vehicles of persons with reduced mobility are needful.

For people with reduced mobility modified communication tools are suitable, e.g., adapted telephone, fax, internet, and for persons with sensory impairments such as sign language or Braille are of course important communication tools.

Inside the buildings of accommodation facilities, monuments, etc., horizontal (elevators) and vertical movements (ramps, stairs) should be adapted and public hygiene facilities should be available (accessible toilet stalls and washbasins).

Tourism is not just about staying in a destination, but it is also about travel. So, passenger vehicles, including private vehicles for hire, buses and coaches, taxis, trams, funiculars (cable cars), trains, commuter ferries and cruise ships should be designed to allow safe, comfortable and equitable transport. Accessible stations and passenger terminals are a matter of course. That means access ramps, elevators, platform lifts, information in visual and acoustic formats.

Disabled visitors have to find accommodation facilities with adapted rooms at a destination, adapted catering facilities, cultural activities such as museums, theatres, cinemas, sports facilities (access to stadiums, race tracks, etc.).

Some tourists are also interested in green spaces and natural environments. A barrier-free natural environment means accessible routes, adapted place for rest, fountains and benches.

Architectural barriers (Tab. 2) are considered most important for the possibility of the physically disabled to participate in tourism. They may be divided into several categories.

It is necessary to keep in mind the fact that areal, volume, and dimensional parameters of premises for disabled people are given by the manoeuvring and dimensional limits of the wheelchair. It is so because these demands are the biggest in terms of space, thus they are spatially suitable even for other groups of disabilities (Samová, Puškár, \& Mikulová, 1999). The dimensions of the wheelchair and the physical abilities of its user are always crucial.

Reach distances of a person in a wheelchair are important typological data in Tab 3. They are

\section{Tab. 2: Overview of architectural barriers according to space requirements}

\begin{tabular}{|c|c|}
\hline Barriers & Characteristics \\
\hline Vertical & $\begin{array}{l}\text { - } \quad \text { stairs } \\
\text { - } \text { height differences }\end{array}$ \\
\hline Horizontal & $\begin{array}{l}\text { - ramp inclination } \\
\text { - surface of walking areas }\end{array}$ \\
\hline Spatial & $\begin{array}{l}\text { - small handling parameters } \\
\text { - inappropriate position of furniture }\end{array}$ \\
\hline Anthropometric & $\begin{array}{l}\text { - reach distances } \\
\text { - } \quad \text { WC height mounting }\end{array}$ \\
\hline Ergonomic & $\begin{array}{l}\text { - the shape of doorknobs, handles, etc. } \\
\text { - inappropriate furnishings and furniture }\end{array}$ \\
\hline Wayfinding and Directional & $\begin{array}{l}\text { - } \text { missing tactile information } \\
\text { - } \quad \text { wayfinding and directional systems and pictograms }\end{array}$ \\
\hline
\end{tabular}




\section{Tab. 3: Crucial dimensions for layout of an interior for a physically disabled person}

\begin{tabular}{l|r|l}
\multicolumn{1}{c|}{ Parameter } & Dimension in $\mathbf{m m}$ & \multicolumn{1}{c}{ Influence on .../importance for ... } \\
\hline height of seat & 520 & height of surface onto which seats are changed \\
\hline length of wheelchair & 1,250 & $\begin{array}{l}\text { layout of the minimum space, e.g., elevator cabin, } \\
\text { WC dimensions }\end{array}$ \\
\hline $\begin{array}{l}\text { height of feet from } \\
\text { ground }\end{array}$ & 220 & $\begin{array}{l}\text { equipment protection from scuffing, furniture } \\
\text { alteration to make it accessible }\end{array}$ \\
\hline width of wheelchair & 900 & width of corridors and doorways \\
\hline height of knees & 670 & height of handling work areas \\
\hline height of armrest & 720 & height of handling work areas \\
\hline
\end{tabular}

Source: Samová, Puškár, \& Mikulová (1999)

used for interior layout and for the positioning of control elements (Samová, Puškár, \& Mikulová, 1999). Reach distances of a wheelchair user are individual and depend on the ability of a given person to move the upper part of their body and their degree of disability. However, the layout of the interior in public buildings is based on maximum, not minimum, reaching abilities of a wheelchair user.

\section{Readiness of Tourism Facilities in the Czech Republic for Visitors with Physical Disabilities}

Accessibility is not only about disabled people but also about older people, families with small children, people with short-term or chronic ailments, etc. In Europe alone, this amounts to an estimated 130 million customers for the tourism industry. In contrast to the huge number of tourists demanding accessible tourism facilities, the share of tourism facilities reported by Member States as being accessible - at least for wheelchair users - amounts to only $1.5 \%$ of restaurants \& catering facilities, $6.5 \%$ of accommodation establishments and $11.3 \%$ of attractions (Neumann, 2008).

\subsection{Aim and Methodology}

The aim of this contribution was to map the possibilities for people with physical disabilities to participate in tourism in the Czech Republic.

Partial aims were also defined:

- To map accessible accommodation facilities which follow legal regulations,

- To map restaurant \& catering facilities accessible for wheelchair users,

- To map culture and historic UNESCO heritage sites and their accessibility for disabled visitors,

- To map barrier-free tourist routes and cycle routes.

Following the partial aims, we hypothesized the existence of an interdependence between the number of visitors and the number of accessible accommodation establishments. At the same time, a hypothesis forms that in regions with a higher share of accommodation establishments of classes $* * * *$ and $* * * * *$ there will be a higher number of barrier-free accommodation establishments available.

To verify the hypothesis, we used correlation analysis, which deals with the dependency ratios of random data. Its standard output is a coefficient describing the dependency rate typically the correlation coefficient. Correlation coefficients serve as a measure expression of "linear constraints tightness". Given the significant differences in the examined data from a normal distribution, we chose the Spearman correlation coefficient.

The Spearman coefficient is based on a comparison of the sequence of values. This coefficient is robust. Its relationship to the classical correlation coefficient is an analogous relationship to the arithmetic median diameter. Coefficient can be written as follow:

$$
\rho_{S p}=1-\frac{6}{n\left(n^{2}-1\right)} \sum_{i=1}^{n}\left(P_{1 i}-P_{2 i}\right)^{2}
$$

where $\mathrm{P} 1, \mathrm{P} 2$ are numbers indicating the order.

We assessed the situation in all administrative regions, while focusing on coverage of the territory with capacity of 
accommodation establishments and restaurant \& catering facilities, on the existence of accessible educational trails, tourist routes, and cycle routes. We were also interested in possibilities to visit UNESCO world heritage sites.

Accommodation establishments were evaluated from the point of view of a barrier-free entrance (designed without levelling stairs, with a ramp, skid or otherwise), and accommodation options for physically disabled people. A barrierfree room is considered a room enabling the handling of a wheelchair, having a barrier-free entrance, and the use of seating furniture, bed, storage space, and featuring an adapted bathroom and toilet (more information in Tab. 4). Important features of hospitality establishments were also barrier-free entrances

\section{Tab. 4: Evaluation criteria - accommodation establishments}

\begin{tabular}{l|c|l}
\multicolumn{1}{c}{ Parameter } & \multicolumn{2}{c}{ Characteristics } \\
\hline entrance & $\checkmark$ & direct with no threshold, with ramp, skid, slightly elevated threshold \\
to building & $\times$ & step or stairs \\
\hline room & $\checkmark$ & entrance to room (no threshold, slightly elevated threshold) \\
& $\checkmark$ & space for turning the wheelchair \\
& $\checkmark$ & furniture adapted for visitors in a wheelchair (seating furniture, bed, wardrobes, \\
& $\times$ & problematic movement in space \\
& $\times$ & non-fulfilment of any of the above points \\
\hline bathroom & $\checkmark$ & entrance to bathroom \\
& $\checkmark$ & space for turning the wheelchair \\
& $\checkmark$ & entrance to shower cubicle or possibility for a person in a wheelchair to enter bathtub \\
& $\checkmark$ & adapted washbasin \\
& $\checkmark$ & adapted toilet \\
& $\checkmark$ & handles in appropriate places \\
& $\checkmark$ & possibility to use bathroom furniture, hairdryer, waste bin \\
& $\times$ & problematic movement in space \\
& $\times$ & non-fulfilment of the condition of barrier-free possibility to perform hygiene \\
\hline
\end{tabular}

Note: $\checkmark$ barrier free, $\boldsymbol{x}$ inaccessible.

\section{Tab. 5: Evaluation criteria - hospitality establishments}

\begin{tabular}{l|c|l}
\multicolumn{1}{c|}{ Parameter } & \multicolumn{2}{c}{ Characteristics } \\
\hline entrance to & $\checkmark$ & direct without threshold, ramp, skid, slightly elevated threshold \\
building & $\times$ & step or stairs \\
\hline sales area & $\checkmark$ & space for turning the wheelchair and transfer of the wheelchair \\
& $\checkmark$ & furniture adjusted for visitors in a wheelchair (tables, bar counter) - respecting \\
& $\checkmark$ & spatial and reaching abilities of a wheelchair user \\
& $\times$ & problematic movement in space \\
& $\times$ & non-fulfilment of any of the above-listed points \\
\hline toilet & $\checkmark$ & entrance to the room \\
& $\checkmark$ & space for turning the wheelchair \\
& $\checkmark$ & adapted washbasin \\
& $\checkmark$ & adapted toilet \\
& $\times$ & handles in appropriate places \\
&
\end{tabular}

Note: $\checkmark$ barrier free, $\mathbf{x}$ inaccessible. 


\section{Tab. 6: Evaluation criteria - tourist routes, cycle routes, educational trails}

\begin{tabular}{l|l|l}
\multicolumn{1}{c|}{ Parameter } & \multicolumn{2}{c}{ Characteristics } \\
\hline surface & $\checkmark$ & $\begin{array}{l}\text { asphalt, sand, gravel, boardwalks, nature trail hardening } \\
\text { step or stairs, stones, historic pavement, tree roots, etc. }\end{array}$ \\
\hline parking* $^{*}$ & & designated parking spaces for health disabled \\
\hline refreshments* $^{*}$ & & $\begin{array}{l}\text { wheelchair accessible (sales window, restaurant, bistro, etc., with barrier-free } \\
\text { access) }\end{array}$ \\
\hline toilet* $^{*}$ & & $\begin{array}{l}\text { entry with a wheelchair } \\
\text { handles in appropriate places }\end{array}$ \\
\hline
\end{tabular}

Note: $\checkmark$ barrier free, $x$ inaccessible, ${ }^{*}$ criteria not evaluated.

to building, the possibility of transferring between tables, comfortable dining, and an adapted toilet (Tab. 5).

As for tourist routes, cycle routes, and educational trails, from the point of view of barrier-free access, we assessed mainly surface finishes suitable for wheelchairs. Parking possibilities, refreshments or barrierfree toilets were welcomed but not necessary for the evaluation of route accessibility for physically disabled people. The reason was that the mentioned infrastructure is often missing even for regular visitors (Tab. 6).

Cultural and historic UNESCO heritage sites are major tourist attractions in several regions of the Czech Republic. Monuments enabling accessibility to at least a part of an exposition (a tour route, church, gardens) for the physically disabled are considered accessible. We were also interested in facilities, such as parking and barrier-free toilet stalls (see in Tab. 7).

The contribution is based on primary and secondary data sources. Among the secondary sources we used mainly professional book and journal literature, recommendations from UNWTO, international documents regarding social tourism and the relevant legislative regulations of the Czech Republic. Furthermore, we used specialised web portals providing information to people with disabilities, databases of tourist information centres, web portals of particular regions, various hotel portals, websites of accommodation and restaurant\&catering establishments, information materials of national parks, etc.

Primary data were obtained from field research within the framework of which we verified barrier-free access found out with the help of secondary research. We personally visited a large number of tourism establishments and attractions. Information about some of the establishments was verified by telephone.

Collecting of primary data took place in 2013 through 2016. The methods of analysis and generalization were used.

\section{Tab. 7: Evaluation criteria - cultural and historic UNESCO heritage sites}

\begin{tabular}{l|c|l} 
Parameter & \multicolumn{2}{c}{ Characteristics } \\
\hline entry & $\checkmark$ & $\begin{array}{l}\text { at least into a part of a building } \\
\text { step or stairs, stones, historic pavement, tree roots, etc. }\end{array}$ \\
\hline services & $\checkmark$ & $\begin{array}{l}\text { min. 1 accessible tour route, exposition } \\
\text { only garden accessible }\end{array}$ \\
\hline parking* $^{*}$ & & designated parking spaces for health disabled \\
\hline toilet* $^{*}$ & & $\begin{array}{l}\text { entry with a wheelchair } \\
\text { handrails in appropriate places }\end{array}$ \\
\hline
\end{tabular}




\subsection{Accommodation Facilities}

As for visitors with physical disabilities, the possibility of their being able to enter accommodation or restaurant\&catering facilities is essential.

The entrance door to the accommodation or restaurant\&catering premises should be minimum $900 \mathrm{~mm}$ wide and $2,000 \mathrm{~mm}$ high. The entrance door, if not operated by electric eye, has to allow opening outwards to a width of minimum $900 \mathrm{~mm}$. Glass windows must be marked with contrasting elements. Guiding and signal lines for blind people are a matter of course.

Tourist enterprises provided with their own car parks should also have parking spaces for disabled people. Adjusted parking places are important especially for accommodation establishments or cultural and social establishments, such as theatres, museums, etc. The total number of designated spaces is rounded up to integers. A minimum of $1 \%$ of total parking spaces must be reserved for health disabled people within establishments providing services (Šestáková, 2011). The minimum dimensions of a parking space should be $5,000 \times 2,200 \mathrm{~mm}$ (some regulations specify a width of $3,500 \mathrm{~mm}$ ). When parked, the wheelchair user should have a space of $1,500 \mathrm{~mm}$ next to the vehicle to get out.

In accommodation establishments, but also in some additional services, such as wellness centres, swimming pools, etc., it is necessary to consider a reception adapted to people in a wheelchair. The reception desk should be low at a minimum of one place in such a way that a person in a wheelchair or a parent with a baby carriage can communicate comfortably with an employee of the reception.

\section{Tab. 8: Share of barrier-free accommodation facilities in regions of the Czech Republic}

\begin{tabular}{l|l|l|l|l|l|l} 
Prague & Central Bohemia & South Bohemia & Hradec Králové & Pardubice & Liberec & Pilsen \\
\hline 18.40 & 10.30 & 9.91 & 1.36 & 2.28 & 11.30 & 8.55 \\
\hline Carlsbad & Ústí nad Labem & Moravian-Silesian & South Moravia & Vysočina & Olomouc & Zlín \\
\hline 20.10 & 10.70 & 7.57 & 8.70 & 11.30 & 11.70 & 16.30 \\
\hline
\end{tabular}

Source: Linderová \& Scholz (2016)

We hypothesized the existence of an interdependence between the number of visitors (Tab. 9) and the number of accessible accommodation establishments. At the same time, a hypothesis forms that in regions with a higher share of accommodation establishments of classes $* * * *$ and $* * * * *$ there will be a higher number of barrier-free accommodation establishments available (Tab. 8).

The term interior communication in tourism establishments can include corridors, lifts, and staircases, but also doors inside the building. Internal communications should be barrierfree and should connect the entrance to the building, e.g., a hotel, with the entrance hall, or the reception, and consequently the reception and barrier-free rooms. The rooms should be provided with access to the restaurant, hotel café, lounges, congress halls, terrace, etc. A matter of course is a barrier-free emergency exit and escape routes. The elevator cabin should have minimum dimensions of $1,100 \mathrm{~mm}$ $x 1,400 \mathrm{~mm}$ and a height of $2,200 \mathrm{~mm}$, the minimum recommended load bearing capacity is $250 \mathrm{~kg}$. The minimum width of the corridor for guests, alternatively visitors, is $1,500 \mathrm{~mm}$, the minimum passable width of a staircase is $1,100 \mathrm{~mm}$.

According to the valid Czech legislation, at least $5 \%$ of rooms in accommodation establishments should be barrier free. The resulting number of rooms is rounded up to integers (Šestáková, 2011). Rooms should be furnished in such a way as to ensure the comfortable movement of people in a wheelchair, with the possibility of grasping and moving. The same conditions also apply to bathrooms, terraces, and balconies. The entrance to the room is provided with a door of minimum width of $900 \mathrm{~mm}$ with a properly designed door handle. In the room, there must be a space of $1,500 \mathrm{~mm}$ diameter to turn the wheelchair. Between individual pieces of 


\begin{tabular}{|c|c|c|c|c|c|}
\hline $\begin{array}{l}\text { Tab. 9: Number } \\
\text { in } 2015\end{array}$ & visitors it & commodation & ablish & $s$ in the & ch Republic \\
\hline Region & $\begin{array}{l}\text { Number } \\
\text { of visitors }\end{array}$ & $\begin{array}{c}\text { Share of foreign } \\
\text { visitors }\end{array}$ & $\begin{array}{l}\text { Number } \\
\text { of AF }\end{array}$ & $\begin{array}{c}\text { Share of } \\
\text { hotels } \\
* * * * * *\end{array}$ & $\begin{array}{c}\text { Share } \\
\text { of accessible AF }\end{array}$ \\
\hline Prague & $6,605,776$ & 87 & 797 & 32.10 & 18.40 \\
\hline Central Bohemia & 907,567 & 23 & 669 & 5.50 & 10.30 \\
\hline South Bohemia & $1,341,912$ & 31 & 1,205 & 2.90 & 9.91 \\
\hline Hradec Králové & $1,124,032$ & 23 & 1,055 & 3.30 & 1.36 \\
\hline Pardubice & 413,443 & 14 & 341 & 2.50 & 2.28 \\
\hline Moravian-Silesian & 775,047 & 23 & 576 & 4.86 & 7.57 \\
\hline Pilsen & 650,250 & 36 & 521 & 4.41 & 8.55 \\
\hline Carlsbad & 850,891 & 63 & 471 & 20.80 & 20.10 \\
\hline Ústí nad Labem & 487,259 & 35 & 468 & 5.76 & 10.70 \\
\hline Liberec & 820,802 & 20 & 892 & 2.20 & 11.30 \\
\hline South Moravia & $1,536,172$ & 32 & 813 & 4.67 & 8.70 \\
\hline Vysočina & 473,712 & 13 & 445 & 4.40 & 11.30 \\
\hline Olomouc & 547,538 & 21 & 465 & 2.58 & 11.70 \\
\hline Zlín & 661,149 & 16 & 455 & 6.74 & 16.30 \\
\hline
\end{tabular}

Source: Czech Statistical Office and own research

Note: AF - accommodation facilities.

furniture is a clearance with a width of $900 \mathrm{~mm}$, at the foot of the bed $1,100 \mathrm{~mm}$. Wheelchair armrests must fit under the writing desk, or dressing table, which must be adapted. The layout of the room should be adapted so that a person in a wheelchair can transfer themselves into the bed, armchair or sofa. The bed should have a height of $450 \mathrm{~mm}$, the bedside table from 500 to $570 \mathrm{~mm}$. The recommended height of the writing desk and dressing table should be $700 \mathrm{~mm}$, the height of tables $800 \mathrm{~mm}$. Opening wardrobes, bedside tables, minibars must be easily manageable and allow easy handling. Visual contrast should be maintained in bathrooms and toilets. This also applies to fixtures and fittings (wash-basin, toilet bowl), handrails and handles. According to the regulations, shower cubicles and stalls have minimum floor-plan dimensions of 1,400 $x 1,400 \mathrm{~mm}$. A non-slip finish and handrails next to the bathtub, shower cubicle, and toilet are a matter of course.

Based on our research between the years 2013 and 2016 we can state that Ústí nad Labem, Liberec, Carlsbad and Prague are the regions with the highest share of barrier-free accommodation facilities. We assumed the highest share in Prague, but there are other regions with a higher share of accessible accommodation facilities, e.g., Carlsbad. On the basis of an evaluation of the Spearman correlation coefficient (see in Tab. 10), we can conclude that the set-out hypotheses cannot be confirmed. The null hypothesis test assumes independence, and with respect to $p$-values greater than 0.05 it was not possible to reject the hypothesis of independence.

It is necessary to state that an interdependency between the number of visitors and the possibility of accommodation for health disabled people in particular regions was not validated. Also, the correlation between a higher number of accommodation establishments and a subsequent higher share of barrier-free accommodation establishments in regions is not valid.

Some relationship can be seen between the number of foreign visitors and a higher share of accessible accommodation establishments (Praha, Carlsbad). 
Tab. 10: Spearman Rank Order Correlations

\begin{tabular}{|c|c|c|c|c|c|}
\hline \multirow{2}{*}{ Variable } & \multicolumn{5}{|c|}{$\begin{array}{c}\text { Spearman Rank Order Correlations (List } 1 \text { in hotels) MD pairwise deleted Marked } \\
\text { correlations are significant at } p<.05000\end{array}$} \\
\hline & $\begin{array}{l}\text { Number of } \\
\text { visitors }\end{array}$ & $\begin{array}{c}\text { Share of foreign } \\
\text { visitors }\end{array}$ & Number of AF & $\begin{array}{c}\text { Share of hotels } \\
* * * *, * * * * *\end{array}$ & $\begin{array}{l}\text { Share of } \\
\text { accessible AF }\end{array}$ \\
\hline Number of visitors & 1.000000 & 0.558504 & 0.841758 & 0.305495 & 0.072607 \\
\hline Share of foreign visitors & 0.558504 & 1.000000 & 0.426053 & 0.580580 & 0.159117 \\
\hline Number of AF & 0.841758 & 0.426053 & 1.000000 & -0.090110 & -0.226623 \\
\hline Share of hotels ${ }^{* \star \star *},{ }^{* * \star * \star}$ & 0.305495 & 0.580580 & -0.090110 & 1.000000 & 0.466447 \\
\hline Share of accessible AF & 0.072607 & 0.159117 & -0.226623 & 0.466447 & 1.000000 \\
\hline
\end{tabular}

Source: own

We also did more detailed research in selected cities in the Czech Republic. In Telč (Vysočina) we found 15\% of accommodation was accessible, e.g., Hotel $U$ hraběnky, Hotel Antoň. In Jeseník (Olomouc region) 13\% of accommodation facilities are accessible, in Olomouc 19\%, in Brno (South Moravia) 19.11\%, in Jihlava (Vysočina) 21.2\%.

\subsection{Catering Facilities}

In restaurant\&catering facilities as well as in hotel restaurants, cafes, etc., it is important to ensure comfortable passage between tables. A passing space width of 800 to $900 \mathrm{~mm}$ is recommended. It is necessary to take into account space to manoeuvre and turn the wheelchair around in a circle with a minimum diameter of $1,500 \mathrm{~mm}$. Dining furniture must be adjusted to the wheelchair so that it is big enough to let the wheelchair fit under. It shall be possible to fit the wheelchair armrests under the dining table. The optimum height of a dining table is 720 to $750 \mathrm{~mm}$. The minimum space at the table is $900 \mathrm{~mm}$ per person. The areas connecting the interior of a restaurant with a terrace or garden should not have a gradient of more than $10 \%$.
Regarding parking spaces, the same guidelines apply as for accommodation establishments.

According to Tab. 11, the highest share of barrier-free or accessible catering facilities can be found in Prague and Carlsbad. What is surprising is the huge number of accessible catering facilities in the Olomouc Region. This may be due to presentations of enterprises promoting themselves as barrier-free via specialized portals. On the grounds of such a presentation the establishment was listed in the barrier-free category of restaurants in the region.

Some of the regions were investigated in more detail. In Jeseník 10\% of catering facilities are barrier-free, in Olomouc around $21 \%$, in Brno $20 \%$, and in Jihlava $13.4 \%$.

\subsection{UNESCO Heritage}

As for the accessibility of cultural and historic monuments, not only the entrance to the building is important but also access communications. Obstructions, such as bins, bicycle stands, etc., shall be removed from the path of travel. The entrance to the building should be provided with at least one entry at the road/communication level without levelling steps. If it is not possible

\section{Tab. 11: Share of barrier-free catering facilities in regions of the Czech Republic}

\begin{tabular}{r|r|r|r|r|r|r} 
Prague & Central Bohemia & South Bohemia & Hradec Králové & Pardubice & Liberec & Pilsen \\
\hline 32.70 & 12.7 & 6.80 & 1.75 & 5.31 & 20.00 & 6.24 \\
\hline Carlsbad & Ústí nad Labem & Moravian-Silesian & South Moravia & Vysočina & Olomouc & Zlín \\
\hline 16.50 & 17.00 & 20.31 & 3.10 & 3.00 & 28.60 & 29.20 \\
\hline
\end{tabular}




\begin{tabular}{|c|c|c|}
\hline \multicolumn{3}{|c|}{$\begin{array}{l}\text { Accessibility of cultural and historic UNESCO heritage sites for people } \\
\text { with physical disabilities - Part } 1\end{array}$} \\
\hline Locality & Site & Description of accessibility \\
\hline \multicolumn{3}{|c|}{ Prague } \\
\hline $\begin{array}{l}\text { Prague - Old } \\
\text { Town }\end{array}$ & $\begin{array}{l}\text { Prague Castle, St. Vitus Cathedral, } \\
\text { St. Wenceslas, Adalbert, St. Mary's } \\
\text { Church, All Saints Church, St. George's } \\
\text { Basilica, Old Royal Palace, Imperial } \\
\text { Stables, The Ball Game Hall, Golden } \\
\text { Lane, Lobkowicz Palace, Royal Garden } \\
\text { of Prague Castle and Summer Palace } \\
\text { of Queen Anne, Schwarzenberg } \\
\text { Palace, Lapidarium, Strahov Monastery, } \\
\text { Charles Bridge, Wallenstein Palace, } \\
\text { Ledebur Garden, Convent of St. Agnes } \\
\text { of Bohemia, Bethlehem Chapel, St. } \\
\text { Nicholas Church/Cathedral }\end{array}$ & $\begin{array}{l}\text { BWC (Prague Castle, Bethlehem } \\
\text { Chapel), barrier-free restaurant (Ledebur } \\
\text { Garden), historic buildings accessible for } \\
\text { immobile visitors always at least partly } \\
\text { (e.g., main and side aisle), interiors } \\
\text { of houses in Golden Lane are not } \\
\text { accessible }\end{array}$ \\
\hline $\begin{array}{l}\text { Prague - } \\
\text { Vyšehrad }\end{array}$ & $\begin{array}{l}\text { Tábor Gate, Gothic vaults, parks } \\
\text { with sculptures, cemetery and Slavín } \\
\text { (Pantheon), Casemates }\end{array}$ & BWC at Basilica of St. Peter and St. Paul \\
\hline Praha - Josefov & $\begin{array}{l}\text { House of Black Madonna, Church of } \\
\text { Our Lady before Tyn, Old Town Hall, Old } \\
\text { Jewish Cemetery, Pinkas Synagogue, } \\
\text { Maisel Synagogue, Spanish Synagogue }\end{array}$ & $\begin{array}{l}\text { historic buildings accessible for immobile } \\
\text { visitors always at least partly }\end{array}$ \\
\hline
\end{tabular}

\begin{tabular}{l|l|l}
\hline \multicolumn{2}{c}{ Central Bohemian Region } \\
\hline Kutná Hora & $\begin{array}{l}\text { St. Barbara's Church, Sázava } \\
\text { Monastery }\end{array}$ & $\begin{array}{l}\text { with a companion, accessible monastery } \\
\text { gardens, exhibitions, Church of St. } \\
\text { Procopius }\end{array}$ \\
\hline $\begin{array}{l}\text { Kutná Hora - } \\
\text { Sedlec }\end{array}$ & All Saints Church with Ossuary & \\
\hline
\end{tabular}

South Bohemian Region

\begin{tabular}{l|l|l}
\hline Český Krumlov & $\begin{array}{l}\text { Castle and stately home, gardens, } \\
\text { Minorit Monastery, St. Vitus Church }\end{array}$ & $\begin{array}{l}\text { pavement in the castle courtyards, } \\
\text { BWC, parking }\end{array}$ \\
\hline Holašovice & Village monument reserve & $\begin{array}{l}\text { movement alongside the road may } \\
\text { be problematic for immobile visitors, } \\
\text { missing pavements }\end{array}$ \\
\hline
\end{tabular}

Pardubice Region

\begin{tabular}{l|l|l}
\hline Litomyšl & $\begin{array}{l}\text { castle, riding hall, birth house of Bedřich } \\
\text { Smetana }\end{array}$ & $\begin{array}{l}\text { for immobile visitors accessible castle } \\
\text { theatre, riding hall through side entry, } \\
\text { BWC, parking }\end{array}$ \\
\hline
\end{tabular}

Moravian-Silesian Region

\begin{tabular}{|c|c|c|}
\hline Olomouc & Holy Trinity Column & BWC nearby \\
\hline \multicolumn{3}{|c|}{ South Moravian Region } \\
\hline Brno & Villa Tugendhat & barrier-free entry, exposition \\
\hline $\begin{array}{l}\text { Lednice } \\
\text { Valtice }\end{array}$ & Lednice Castle & $\begin{array}{l}\text { barrier-free only one tour, former castle } \\
\text { riding hall, French garden and park, } \\
\text { palm conservatory (it is necessary to get } \\
\text { over } 4 \text { steps), BWC, parking }\end{array}$ \\
\hline
\end{tabular}




\begin{tabular}{|c|c|c|}
\hline Tab. 12: & \multicolumn{2}{|c|}{$\begin{array}{l}\text { Accessibility of cultural and historic UNESCO heritage sites for people } \\
\text { with physical disabilities - Part } 2\end{array}$} \\
\hline \multicolumn{3}{|c|}{ Vysočina Region } \\
\hline Telč & castle & $\begin{array}{l}\text { for the immobile accessible only tour } \\
\text { C/gallery, garden and park, parking on } \\
\text { the square, BWC }\end{array}$ \\
\hline Třebíč & $\begin{array}{l}\text { Jewish Quarter, St. Procopius Basilica, } \\
\text { Front Synagogue, Jewish Cemetery }\end{array}$ & $\begin{array}{l}\text { historic pavement, accessible main } \\
\text { cathedral aisle, for the immobile } \\
\text { inaccessible crypt, accessible gardens, } \\
\text { accessible ground floor of Front } \\
\text { Synagogue, 3x BWC (Eurokey, skid, par } \\
\text { of tourist information centre), parking }\end{array}$ \\
\hline $\begin{array}{l}\text { Žd'ár nad } \\
\text { Sázavou }\end{array}$ & $\begin{array}{l}\text { Pilgrimage Church of St. John of } \\
\text { Nepomuk at Zelená hora/Green Hill }\end{array}$ & $\begin{array}{l}\text { entry with the help of ramps, parking, } \\
\text { educational trail cannot be used }\end{array}$ \\
\hline \multicolumn{3}{|c|}{ Zlín Region } \\
\hline Kroměříž & $\begin{array}{l}\text { Archbishop's Castle, Castle Garden and } \\
\text { Baroque Flower Garden }\end{array}$ & BWC \\
\hline
\end{tabular}

Source: own

to ensure entry this way, the levelling shall be resolved by a ramp, staircase landing, or outside lift. If barrier-free entry for wheelchairbound people to the building is not possible due to heritage conservation, it is appropriate to ensure at least access for people with reduced mobility and the ability to orientate themselves.

Based on the results of the conducted survey in Tab. 12, it can be stated that each monument is partially prepared for visits by people with disabilities. However, due to the historical value of the buildings being preserved, frequently only parts of them are made accessible. Nevertheless, the greatest attention is paid to persons with physical disabilities. Often, a barrier-free toilet or refreshments are not available.

\subsection{Greenways}

There is a need to modify the surface to ensure access to natural monuments, parks, or the use of cycle routes. Suitable is an asphalt finish, gravel, alternatively sand or boardwalks.

\section{Tab. 13: Barrier-free routes in the Czech Republic by region - Part 1}

\begin{tabular}{l|c|l}
\multicolumn{1}{c|}{ Attraction } & Number of routes & \multicolumn{1}{c}{ Comment } \\
\hline \multicolumn{4}{c}{ South Bohemian Region } \\
\hline educational trails & 10 & NP Šumava \\
\hline tourist routes & 10 & CHKO Třeboňsko, Český Krumlov, Lipno \\
\hline cycle routes & 1 & Frymburk - Lipno nad Vltavou \\
\hline skiing trails & 1 & Ski resort Lipno \\
\hline \multicolumn{3}{c}{ Plzeň Region } \\
\hline educational trails & 37 & 2 accessible only with a companion \\
\hline cycle routes & - & No information on barrier-free access \\
\hline \multicolumn{3}{c}{ Karlovy Vary Region } \\
\hline educational trails & 6 & CHKO Slavkovský les (2) \\
\hline \multicolumn{3}{c}{ Ústí nad Labem Region } \\
\hline tourist routes & 11 & NP České Švýcarsko (6), CHKO České Středohoří (5) \\
\hline cycle routes & 6 & NP České Švýcarsko (4), CHKO Labské pískovce (2) \\
\hline
\end{tabular}




\section{Tab. 13: Barrier-free routes in the Czech Republic by region - Part 2}

\begin{tabular}{|c|c|c|}
\hline Attraction & Number of routes & Comment \\
\hline \multicolumn{3}{|c|}{ Liberec Region } \\
\hline tourist routes & 43 & $\begin{array}{l}\text { CHKO Lužické hory (8), CHKO Jizerské hory (15), } \\
\text { CHKO Český ráj (20) }\end{array}$ \\
\hline ski trails & 3 & $\begin{array}{l}\text { Ski resort Bedřichov, Ski resort Tanvaldský Špičák, } \\
\text { Ski resort Javorník }\end{array}$ \\
\hline \multicolumn{3}{|c|}{ Hradec Králové Region } \\
\hline tourist routes & 28 & $\begin{array}{l}\text { NP Krkonoše (10), CHKO Český ráj (2), CHKO } \\
\text { Orlické hory (2), CHKO Broumovsko (6) }\end{array}$ \\
\hline educational trails & 5 & CHKO Orlické hory \\
\hline cycle routes & 13 & total length: $52.2 \mathrm{~km}$ \\
\hline \multicolumn{3}{|c|}{ Pardubice Region } \\
\hline tourist routes & 1 & CHKO Orlické hory, CHKO Železné hory \\
\hline educational trails & 8 & 2 accessible only with a companion \\
\hline cycle routes & 31 & total length: $99.4 \mathrm{~km}$ \\
\hline \multicolumn{3}{|c|}{ Central Bohemian Region } \\
\hline $\begin{array}{l}\text { tourist routes } \\
\text { cycle routes }\end{array}$ & $\begin{array}{l}3 \\
6\end{array}$ & $\begin{array}{l}\text { CHKO Český kras, CHKO Blaník, CHKO Kokořínsko, } \\
\text { CHKO Křivoklátsko* }\end{array}$ \\
\hline \multicolumn{3}{|r|}{ Prague } \\
\hline tours of the town & 10 & e.g. Vyšehrad, through Staré Město to Josefov \\
\hline cycle routes & 3 & $\begin{array}{l}\text { Praha-Klecany }(1.7 \text { km), Podolí-Zbraslav }(10.9 \text { km), } \\
\text { Vltavská magistrála }(10 \mathrm{~km})\end{array}$ \\
\hline \multicolumn{3}{|c|}{ Vysočina Region } \\
\hline educational trails & 13 & CHKO Žd'árské vrchy \\
\hline cycle routes & 5 & \\
\hline \multicolumn{3}{|c|}{ South Moravian Region } \\
\hline educational trails & 12 & CHKO Pálava, Lednicko-Valtický area \\
\hline cycle routes & 6 & NP Podyjí, CHKO Pálava \\
\hline \multicolumn{3}{|c|}{ Zlín Region } \\
\hline educational trails & 4 & CHKO Beskydy, CHKO Bílé Karpaty \\
\hline skiing trails & 2 & Ski resort Razula, Ski resort Troják \\
\hline \multicolumn{3}{|c|}{ Olomouc Region } \\
\hline educational trails & 8 & CHKO Jeseníky, CHKO Litovelské Pomoraví \\
\hline skiing trails & 5 & $\begin{array}{l}\text { Ski resorts Kareš, Ramzová, Petříkov, Kraličák, } \\
\text { Kladky }\end{array}$ \\
\hline \multicolumn{3}{|c|}{ Moravian-Silesian Region } \\
\hline tourist routes & 31 & CHKO Beskydy (16), CHKO Jeseníky (5) \\
\hline educational trails & 16 & CHKO Poodří (5), CHKO Beskydy (9) \\
\hline cycle routes & 17 & $\begin{array}{l}\text { CHKO Poodří (1), CHKO Beskydy (8), CHKO } \\
\text { Jeseníky (2) }\end{array}$ \\
\hline
\end{tabular}


Steeper sections should be fitted with railings or ramps.

In the case of leisure activities and sports in a natural environment, the Czech Republic offers barrier-free routes, educational trails, and cycle routes (see in Tab. 13). However, people with physical disabilities face many problems. Markings on barrier-free routes and trails are not unified. Some areas, e.g., Krkonoše, mark wheelchair-accessible pathways with pictograms. Barrier-free routes are marked out mainly in areas where "barrierfree" projects were carried out, i.e., Šumava, Krkonoše, Beskydy. The Czech Tourist Club also participates in marking routes suitable for the wheelchair bound. However, this initiative proceeds slowly due to financial demands. Information on accessibility of tourist routes, educational trails, and cycle routes is difficult to obtain. In some places, the information is provided by tourist information centres or the national park service or protected area service. However, many routes are not provided with this information. For the wheelchair bound, information on the surface (asphalt, forest tracks, gravel) of the given route is also essential. This information enables them to make a decision about a particular route.

\section{Conclusion and Discussion}

Major worldwide events, such as the Paralympics, have shown globally how people with disabilities can lead independent, successful lives and play a full role in society (Darcy \& Buhalis, 2011).

Disabled people's interest in travel, getting to know new things, recreation or culture is on the rise, regardless of their type of disability. Integration of people with disabilities into regular life is being resolved at a constantly growing rate. In many cities or holiday destinations, the public transport, public service buildings (post offices, banks, hospitals), stores, etc., are becoming completely or partly barrier free. Projects aimed at creating barrier-free access have been carried out, e.g., in Bordeaux, Barcelona, and in the Czech Republic, e.g., Olomouc. Areas with attractive primary offer for tourism are joining these initiatives. Among examples of good experience are, e.g., Valencia with its accessible beaches, Girona with the making of accessible tourist routes, Vienna with its special information portal for the hearing impaired, United Kingdom and Paris with their specialized web guides, etc. We ought to name, e.g., Krkonoše and Beskydy among others in the Czech Republic.

Disabled visitors are undoubtedly an interesting segment for tourism enterprises. In addition to the fact that they often travel with an assistant, which automatically increases the number of visitors, some of them look to travel outside the main tourist season. They therefore belong in the segments of visitors which can help enterprises to bridge seasonal fluctuations and make the tourist season longer. They look for services modified to their disadvantages and this is another reason for their coming back with pleasure to places where they have been satisfied.

The aim of this contribution was to map the possibilities of people with disabilities to participate in all tourism in the Czech Republic. We evaluated the situation in all administrative regions, while focusing on coverage of the territory with capacity of accommodation and restaurant\&catering establishments, on the existence of accessible educational/nature trails, tourist routes, and cycle routes. We were also interested in the possibility of visiting UNESCO heritage sites.

On the basis of the conducted analysis, we can conclude that the situation in the Czech Republic in the area of accessible tourism is not particularly positive. The average share of barrier-free accommodation establishments in the country is $11 \%$ and $12 \%$ in restaurant\&catering establishments. The presumption is that regions with a higher number of accommodation establishments of a higher standard (First Class ${ }^{* * * *}$, Luxury ${ }^{* * * * *}$ ) have a higher share of accessible ones. However, we can say that a higher share of barrier-free accommodation establishments is available in regions with a greater primary offer of tourism (Prague, Carlsbad).

We presumed that restaurant\&catering establishments would be better adjusted to physically disabled clients. A frequent drawback is too narrow spaces to get wheelchairs between tables, a missing or poorly designed toilet stall for the disabled. In such a case, even an establishment with a barrier-free entrance shall not be considered barrier free for the disabled.

Leisure-time activities and sports also belong to tourism. Therefore, in our research we focused on the accessibility of educational/ 
nature trails, tourist routes, and cycle routes. According to Tab. 13 we can say that regions with national parks or attractive natural sites, such as Český ráj, Krkonoše, Šumava, České Švýcarsko, are best prepared.

When we compare situation in the Czech Republic with traditionalle social tourism countries as France or Spain, we state some differencies. France has redesigned raiting system of accessible accommodation facilities. Accommodation facilities and other tourism atractivites can be part of Tourisme et Handicaps Brand. It is a response to the demand of people with disabilities who want to choose their holidays and leisure freely. The brand provides a guarantee of an efficient welcome to the essential needs of the disabled. At the end of the year 2016 already more than 5.5 thousand facilities were assigned to the brand. Majority of them are accommodation facilities (57\%), restaurants ( $8 \%)$, monuments and sightseeings $(12 \%)$, other atractions as aquaparks, casinos, beaches (12\%) (Tourisme et Handicaps, 2016). Spain is oriented on seniors and disabled visitors as well. The national organization
Imserso provides benefits in social tourism visitors. The hotel chain Paradores also works here. All Paradores hotels have to be fully accessible for wheelchair users. Some regions as Valencia or Catalonia have prepared accessible plans for tourism atractivities. State and municipalities in both of these countries are focused on accessible environment for all. Both countries have programmes of senior travellers and disabled travellers support. Evaluating and labelling of accessible tourism facilities is in both countries in the competence of a specialized organization and supported by government. Best practices we can find also in Great Britain, where governmental support for families with disabled children works.

In the Czech Republic there is evaluating of accessible atractivites still private inciative and no united system of evaluating works. Therefore, some incorrect information is presented e.g. accessible accommodation without access to restaurant, accessible access to castle without possibility to visit first or second floor or accessibility without accessible restrooms etc.

\section{Tab. 14: Accessible tourism facilities and attraction in the Czech Republic}

\begin{tabular}{l|c|c|c|l} 
Region & $\begin{array}{c}\text { Share of accessible } \\
\text { accommodation } \\
\text { facilities (\%) }\end{array}$ & $\begin{array}{c}\text { Share of catering } \\
\text { facilities } \\
\text { (\%) }\end{array}$ & $\begin{array}{c}\text { Greenways } \\
\text { (hiking trails, } \\
\text { cycle routes) }\end{array}$ & \multicolumn{1}{|c}{$\begin{array}{c}\text { UNESco } \\
\text { heritage }\end{array}$} \\
\hline Prague & 18.40 & 32.70 & 13 & Prague \\
\hline Central Bohemia & 10.30 & 12.70 & 9 & Kutná Hora \\
\hline South Bohemia & 9.91 & 6.80 & 21 & \\
\hline Hradec Králové & 1.36 & 1.75 & 46 & \\
\hline Pardubice & 2.28 & 5.31 & 40 & Litomyšl \\
\hline Moravian-Silesian & 7.57 & 20.31 & 64 & \\
\hline Pilsen & 8.55 & 6.24 & 37 & \\
\hline Carlsbad & 20.10 & 16.50 & 6 & \\
\hline Ústí nad Labem & 11.60 & 3.70 & 17 & \\
\hline Liberec & 11.20 & 3.40 & 43 & \\
\hline South Moravia & 8.70 & 3.10 & 18 & Brno, Lednice \\
\hline Vysočina & 11.30 & 3.00 & 18 & $\begin{array}{l}\text { Telč, Třebíč, Žd'ár } \\
\text { nad Sázavou }\end{array}$ \\
\hline Olomouc & 11.70 & 28.60 & 8 & Olomouc \\
\hline Zlín & 16.30 & 29.20 & 6 & \\
\hline
\end{tabular}


The situation in the Czech Republic in the area of providing disabled people with tourism services is improving in comparison with the past. Trips, package tours or stays for such clientele are still neglected. We can state that the Czech Republic has accommodation, restaurant\&catering establishments, possibilities to visit natural attractions, and cultural and historic monuments accessible for the disabled. The offer is distributed unevenly in the country and it is difficult to draw up a particular product for several days so that comforts for the visitor are ensured.

The aforesaid analysis provides a summary of the situation in providing tourism services for the physically disabled in Tab. 14. In regard to the results, the limitations of the conducted analysis ought to be mentioned. Even though the field research took place over the course of three years and was considerably extensive across the board, the stated results cannot be considered exhaustive. Account must be taken of the fact that there is an ongoing process of dismantling barriers and adapting the environment to people with physical disabilities. For more detailed and exhaustive knowledge of the situation, it is desirable to undertake partial research focused on particular cities/towns or tourist areas.

The carried-out research represents the input data for extensive mapping of the situation within the framework of smaller areas. Orientation towards social tourism, and discussions on possibilities of adapting tourist attractions for people with disabilities are a topical issue in the actual demographic trend of an aging population not only in Europe but also in the Czech Republic. It is necessary to emphasize the importance of barrier-free solutions not only for the disabled but also for seniors, parents with strollers or people with temporary restrictions in movement.

The data obtained by the carried-out survey are shared with mapybezbarier.cz portal, which is an initiative of the Charter 77 Foundation - Barriers Account. An interactive informative map portal is being created following demands by wheelchair-bound people. The portal maps several hundred buildings in the Czech Republic, but far from all of them. The data obtained from research are shared, reviewed and gradually put into the information database which provides information to the disabled.
Mapping barrier-free objects of tourism is not that regular.

In some cities or destinations there is brief information with an offer of barrier-free accommodation which is dealt with mostly by a destination management organization, sometimes this information is provided by an organization of persons with disabilities. Most often, however, they are aware only of tourist facilities which present themselves as barrier-free on their websites. Around the world there are several initiatives, for example, wheelchairtraveling.com or wheelmap.org. But this means mapping objects that guide groups of enthusiasts, mostly in wheelchairs, and therefore portals provide brief information only on sites that have been visited by the initiators personally.

For the future of social tourism and tourism by people with health disabilities, it is important not only to map the accessibility of individual buildings but also to raise awareness of the needs of disabled passengers, making the environment barrier-free, etc. This can be helped by practical workshops and mapping the situation in cities, towns, and neighbouring countries, e.g., in the Slovak Republic and Poland, where this issue is gradually getting more attention.

This article was processed with a contribution from project SGS-2017-007 Business environment as a factor of regional development by the Faculty of Economics, University of West Bohemia.

\section{References}

Buiga, A., Stegerean, R., Chiş, A., \& Lazăr, D. (2017). Pricing of the Tourism Product: A Tool for Entrepreneurs to Adapt to a Flexible Market. E\&M Ekonomie a Management, 20(1), 172-186. doi:10.15240/tul/001/2017-1-012.

Buřvalová, D., \& Reitmayerová, E. (2007). Tělesně postižený. Praha: Vzdělávací institut ochrany dětí.

Darcy, S. (2010). Inherent complexivity: disability, accessible tourism and accommodation information preferences. Tourism Management, 31(6), 816-826. doi:10.1016/j.tourman.2009.08.010.

Eichorn, V., Miller, G., \& Tribe, J. (2013). Tourism: a site of resistance strategies of individuals with a disability. Annals of Tourism Research, 43, 578-600. doi:10.1016/j.annals.2013.03.006. 
Filipiová, D. (1998). Život bez bariér: projekty a rekonstrukce. Praha: Grada Publishing.

Garcés Ferré, J., Ferri Sanza, M., Durá Ferrandis, E., McCabe, S., \& Sanchez Garcia, J. (2015). Social tourism and healthy ageing. International Journal of Tourism Research, 18(4), 297-307. doi:10.1002/jtr.2048.

Leidner, R. (2006). Tourism accessible for all in Europe. NatKo - Nationalekoordinationstelle Tourismus für Alle e. V. NatKo. Retrieved March 9, 2016, from http://www.rollingrains. com/archives/Tourism_for_all_in_Europe_ Leidner_2006.pdf.

Leidner, R. (2008). Tourism accessible for all in Europe. Ehical: Barrier Free Tourism. Retrieved December 16, 2016, from www.tourism-review. com/fm485/ethical-barrier-free-tourism.pdf.

Linderová, I. (2015). Accessible tourism services for disabled visitors in South Bohemia Region. In Proceedings of the 4th Biannual CER Comparative European Research Conference (pp. 33-37). London, United Kingdom: CER.

Linderová, I., \& Scholz, P. (2016). Accessible Tourism Services on an Example of Accommodation Facilities in Prague. In K. Soliman (Ed.), Proceedings of the 27th International Business Information Management Association Conference: Innovation Management and Education Excellence Vision 2020 - From Regional Development Sustainability to Global Economic Growth. Milan: IBIMA.

Lovelock, B., \& Lovelock, K. M. (2013). Ethics of Tourism. Critical and Applied Perspectives. New York: Routledge.

Maráková, V., Dyr, T., \& Wolak-Tuzimek, A. (2016). Factors of Tourism's Competitiveness in the European Union Countries. E\&M Ekonomie a Management, 19(3), 92-109. doi:10.15240/ tul/001/2016-3-007.

McCabe, S. (2009). Who needs a holiday? Evaluating social tourism. Annals of Tourism Research, 36(4), 667-688. doi:10.1016/j. annals.2009.06.005.

McCabe, S., Joldersma, T., \& Li, C. (2010). Understanding benefits of social tourism: linking participation to subjective well-being and quality of life. International Journal of Tourism Research, 12(6), 761-773. doi:10.1002/jtr.791.

Michopoulou, E., Darcy, S., Ambrose, I., \& Buhalis, D. (2015). Accessible tourism future: the world we dream to live in and the opportunities we hope to have. Journal of Tourism Futures, 1(3), 179-188. doi:10.1108/ JTF-08-2015-0043.
Minnaert, L. (2014). Social tourism participation: The role of tourism inexperience and uncertainty. Tourism Management, 40, 282-289. doi:10.1016/j.tourman.2013.07.002.

Neumann, P. (2008). Case study: Economic advantages of accessible tourism in Germany. Ehical: Barrier Free Tourism. Retrieved December 16, 2016, from www.tourism-review. com/fm485/ethical-barrier-free-tourism.pdf.

Novosad, L., etal. (2005). Občané se zdravotním postižením a veřejná správa. Olomouc: Výzkumné centrum integrace zdravotně postižených.

NIS - Nábytkářský informační system. (2013). Bezbariérový nábytek. Retrieved June 03, 2016, from http://www.n-i-s.cz/cz/ bezbarierovy-nabytek/page/336/.

Rahman, K. (2005). Accessible Tourism for All. Retrieved March 10, 2016, from www. un.org/.../desa/df_1_kazi_rahman_add.1.doc.

Renotiérová, $\bar{M}$. (2006). SomatopedieAndragogika. Olomouc: Univerzita Palackého v Olomouci.

Samová, M., Puškár, P., \& Mikulová, Z. (1999). Bývanie bez bariér. Architektonická príručka navrhovania rodinných domov a bytov pre osoby s obmedzenou schopnost'ou pohybu. Prvá stavebná sporitel'ňa.

Šestáková, I. (2011). Bezbariérová řešení staveb. Praha: ČVUT. Retrieved July 31, 2016, from https://www.fa.cvut.cz.

Scholz, P., \& Linderová, I. (2016). Možnosti sportovního vyžití pro tělesně postižené návštěvníky cestovního ruchu $v$ České republice. Studia Turistica, 7(1), 18-34.

Shi, L., Cole, S., \& Chancellor, H. C. (2012). Understanding leisure travel motivations of travellers with acquired mobility impairments. Tourism Management, 33(1), 228-231. doi:10.1016/j.tourman.2011.02.007.

Tourisme et Handicaps. (2016). Presentation of the Tourism and Handicap Brand. Retrieved September, 2017, from http:// www.tourisme-handicaps.org/les-labels/.

UNWTO. (2005). Accessible Tourism for All. Retrieved December 16, 2016, from http://www2.unwto.org/sites/all/files/docpdf/ 2005resolutionaccessibletourismforall.pdf.

Vítková, M. (1998). Paradigma somatopedie. Brno: Masarykova univerzita.

WHO. (1980). International Classification of Impairments, Disabilities and Handicaps. Geneva: WHO. Retrieved December 16, 2016, from http://apps.who.int/iris/ bitstream/10665/41003/1/9241541261_eng.pdf. 
Ing. Ivica Linderová, PhD. College of Polytechnics Jihlava Department of Travel and Tourism ivica.linderova@vspj.cz
Ing. Petr Janeček University of West Bohemia

Faculty of Economics

Department of Marketing, Trade and Services janecp00@kmo.zcu.cz 


\section{Abstract}

\section{ACCESSIBLE TOURISM FOR ALL - CURRENT STATE INTHE CZECH BUSINESS AND NON-BUSINESS ENVIRONMENT}

\section{Ivica Linderová, Petr Janeček}

Tourism is a sector of remarkable economic importance. Nowadays, new ways to develop tourism are being discovered. One of them is accessibility and social policy aspects.

The aim of the paper is to map the possibilities for people with physical disabilities to participate in tourism in the Czech Republic.

Following the aim, the article hypothesizes the existence of an interdependence between the number of visitors and the number of accessible accommodation establishments. At the same time, a hypothesis forms that in regions with a higher share of accommodation establishments of classes **** (First Class) and ${ }^{* * * * *}$ (Luxury) there will be a higher number of barrier-free accommodation establishments available.

It assesses the situation in all administrative regions while focusing on coverage of the territory with the capacity of accommodation establishments and restaurant \& catering facilities, on the existence of accessible educational trails, tourist routes, and cycle routes. The article is also interested in possibilities to visit UNESCO world heritage sites.

On the basis of the conducted analysis, it is possible to conclude that the situation in the Czech Republic in the area of accessible tourism is not particularly positive. The average share of barrier-free accommodation establishments in the country is $11 \%$ and $12 \%$ in restaurant\&catering establishments.

The most accessible routes, cycle routes, etc., are found in regions with national parks or attractive natural sites, such as Český ráj, Krkonoše, Šumava, and České Švýcarsko.

The situation in the Czech Republic in the area of providing disabled people with tourism services is improving in comparison with the past.

Key Words: Accessibility, accommodation facilities, disability, greenways, social tourism.

JEL Classification: L83, Z32.

DOI: 10.15240/tul/001/2017-4-012 